\title{
SHELTER EDUCATORS: CONCEPTIONS ON DEVELOPMENT AND CARE PRACTICES IN PLAY SITUATION
}

\author{
Laiane da Silva Corrêa ${ }^{1}$, Lília Iêda Chaves Cavalcante²
}

\begin{abstract}
Recent researches have pointed out the need of studying collective children care environments with an emphasis on the educator's role and its continued interaction with the physical and social environment, its care practice and its psychology. The aim of the present study was to investigate the conceptions about child development and the educators' care practices of a child care institution. Took part in this study 100 educators responsible for the daily care of children refereed to a children care institution who answered the Knowledge of Infant Development Inventory. According to their performance on child development 10 educators were selected to be observed in their daily care routine of children, especially in play situation. The results show that most professionals are women $(99 \%), 35$ years old or older, who have children, finished high school and have at least 24 months of experience as educator. Besides, it was verified that $66 \%$ of the educators answered correctly an average of 66 questions. The personal and family experience as mother or father and educator was demonstrated to be a significant variable for the greater the amount of children and the experience, the grater the level of knowledge on the subject. It was also observed that the level of knowledge on the subject is an equally relevant variable for the quality in the interactions and care offered to the children. It is concluded that in the presence of both conditions the children are benefited for they tend to be more stimulated, oriented and taught in a play environment, such care practices are essential in the promotion of development.
\end{abstract}

Key words: conceptions on development, care practices, educators, institutional care, play.

\section{INTRODUCTION}

Studies have been giving today more importance to the notion of development-in theenvironment. The concept of developmental niche follows this pragmatic orientation and proposed researches that try to capture the continued and mutual interaction between the environment, the educators' psychology and their habitual and ritualized practices ${ }^{1,2,3}$, understanding them as subsystems of the family and institution developmental context.

In this sense, the family is a developmental niche that has been studied as a primary and broadening context, focusing almost always on parental ethnotheories $4,5,6$, practices and education styles and the mother's care ${ }^{7,8}$, father's care ${ }^{9}$ and/ or other responsible relative ${ }^{1,10}$. Although the family has been recognized as a broad developmental context by its set of functions socially attributed, it cannot be held as the only one in terms of developmental pathway, as it has been increasingly sharing with institutions for children ${ }^{11,12}$ the care and education of younger generations.

Nowadays, children have spent part of their time in institutions for children, whether in day care centers, part time of full time schools, or care centers for children with risk to their physical, psychological or sexual integrity.

Among institutions for children in early childhood, schools and day care centers have been privileged environments for researches on the quality of the school environment, the profile and practices of educators, as well as aspects concerning their formation and knowledge on themes related to the bio-psycho-social development and

1 Psicóloga e Mestre em Teoria e Pesquisa do Comportamento pela Universidade Federal do Pará. Bolsista de Mestrado pela CAPES. Este artigo é parte da Dissertação de Mestrado intitulada: Concepções de desenvolvimento e práticas de cuidado à criança em ambiente de abrigo na perspectiva do Nicho Desenvolvimental. Defendida em 28/04/11 pelo Programa de Pós-Graduação em Teoria e Pesquisa do Comportamento na UFPA, orientada pela segunda autora.

2 Professora/Orientadora do Programa de Pós-Graduação em Teoria e Pesquisa do Comportamento, Universidade Federal do Pará. Corresponding Author: Iai_correa@yahoo.com.br

Suggested citation: Corrêa LS, Cavalcante LIC. Shelter educators: conceptions on development and care practices in play situation. Journal of Human Growth and Development 2013, 23(3): 309-31

Manuscript submitted Jan 01 2013, accepted for publication Jul 072013. 
learning ${ }^{10}$. Nonetheless, the child care institutions, where the child is 24 hours a day, have been provoking, nowadays, great concern between the scholars of child development with the quality of the physical and social environment, the psychology of educators that work in it and their institutionalized practices.

Examining the literature it was verified that studies on the subsystem that compose the developmental niche such as schools, day care centers and child care institutions, are more common when they are investigated individually rather than the interacting dynamic between them. That is the case, mainly, of researches that analyze the relation between the development conceptions and care practices in collective environments other than the child's original family. In Brazil it may be affirmed that such studies are rare and must be motivated by Psychology and similar areas.

According to such perspective this study seeks to analyze the possible relations between the level of knowledge and the care practice of educators in sheltering institutions, considering as context for the register of observational data the play situations. The conceptions of development gather more repertoire than only the knowledge about what it is to play, but everything else that concerns the play in the care routine in the early years of childhood, in the milestone of the neuropsychomotor maturation, and in the decisive phases for the acquisition of important skills. The literature ${ }^{11,13,14}$ shows that the play has an important role in the developmental pathway, demanding from the child educator the domain of its theoretical basis and routines capable of promoting social learning and emotional maturation through play situations.

Facing this context the aim is to investigate aspects of the caretakers' routine in play situations, in addition to verify the knowledge and conceptions about child development and observing the care practices among educators in a sheltering institution.

\section{METHODS}

\section{Participants}

Were interviewed 100 educators that represented $95.23 \%$ of the professionals responsible by the daily care of children aging between 0 and 6 years old, sent to a child shelter institution between the years of 2009 and 2010 . From them, 10 educators were selected and took part of observational sessions of its care practices, the main choice criterion was their performance in the Knowledge of Infantile Development Inventory.

\section{Environment}

The care center is an institution from the govern that attends children in a social vulnerability situation, aging between zero and six years old in the city of Belém, in the state of Pará. It has the capacity for 50 children, though it frequently fits 80 children per month.

\section{Instruments and Materials}

In order to gather information about some subjects regarding the child development it was used the Knowledge of Infant Development Inventory presented by MacPhee ${ }^{15}$. In Brazil it was translated and adapted by Seidl de Moura et al. ${ }^{16}$. The instrument assesses the knowledge of educators about the developmental pathway, most probable periods for the acquisition of motor, perceptual and cognitive skills, factors related to the principles of development, parental practices, and care with feeding, hygiene and safety. The inventory was adapted to be used with educators, adjusting the content to the assessed population. The questionnaire is composed by 75 questions, divided into 4 categories according to Macphee ${ }^{15}$ : parental care (14 items), developmental norms and milestones (32 items), principles (17 items) and health (12 items).

\section{Procedure}

Initially it was requested to the Ethics Committee a judicial authorization to perform the research, which judged in favor of the proposed aims and method through the document $n^{\circ} 018 / 08$ CEP-ICS/UFPA, in addition, a consent form was signed by the person legally responsible for the chosen sheltering institution. The researchers attended at least three times a week the different environments of the institution. The idea was to make the researchers comfortable to the presence of the researchers, to mutually see and be seen, without substantially interfering in the care routine. In the continuance the KIDI was applied for the participants in the institution.

The educators were asked to sign the Informed Consent (IC) where the main objects of the research were informed and it was requested their authorization to partake in the process. In the continuance, in the observation phase, 10 educators were accompanied chosen by their performance in the KIDI. The goal of this phase was to observe the care practices of educators that had higher and lower scores in the rank that informs about the percentage of right, wrong and uncertain answers presented by the educator in each category of the instrument.

It is important to highlight that the educators were observed by the researchers in different moment of their working routine. Therefore, the observation period of each focal subject was of 12 sessions lasting one hour each, accomplished in 12 different days. At the end of the data collection 120 sessions were performed, adding 120 hours of observation of the educators and their practices.

\section{Data Analysis}

The data collected in reference to the characterization of educators and the inventory were 
organized in sheets from the Excel software (Microsoft). At the end statistical test were perform in order to verify the influenced played by certain characteristics of educators on the number of right answers from the instruments' questions.

With the videos in hand the content of the observed sessions were transcribed in standard register sheet giving emphasis to aspects of the environment in which the session happened, general characteristics of the caretaker and the children interacting with the focal subject. Next, some moments in which each caretaker was involved in play situations were selected. From such moments some episodes were extracted to illustrate the care practices and routine activities in the researched institution. This content was analyzed based on categories inspired by and adapted from Piccinini, Frizzo and Marin ${ }^{9}$ :

1) Orients about the nature, function and rules of playing: the educator highlights to the child eminent danger situations, identifies norms, attitudes, and general aspects involved in playing.

2) Stimulates, encourages and challenges to split and share toys and plays: the educator offers toys, motivates the playing, inserts toys and involves the children in new activities, in order to promote the socialization of these materials among the children in the group. Uses constantly social reinforcement as compliments and words that motivate the commitment to activities.

3) Teaches concepts and the right pronunciation when speaking: the educator instructs the child about several concepts, colors, numbers, body parts, elements that are part of a set, fruit names, and the right pronunciation of words and sentences.

Two researchers took part in the development of the categories system, analyzing independently the material corresponding to $30 \%$ of the sessions. The divergences were discussed and solved by consensus, with an agreement level higher than $80 \%$.

Though the analysis of the practices content and its organization into categories, some extracts were identified in the transcription of the observational data that differentiate its occurrence in each group ( $\mathrm{G} 1$ and G2). Lastly, some possible relations between the knowledge assessed by KIDI on child development and care practices found in each group according to the adopted categories were discussed.
The participants were identified in the sessions extracts by codes, the children were represented by the letter $\mathrm{C}$ and number corresponding to their dormitory in ascending order from D1 (zero to six months), D2 (seven to twelve months), D3 (13 to 24 months), D4 (25 to 36 months), D5 (37 to 48 months), D6 (49 to 60 months) and D7 (61 to 72 months). The focal educators were represented by the letters " $\mathrm{G} 1$ " and "G2", which represent the sample they are part, and the letter " $E$ " followed by the number which represents its allocation in the group, considering the number of right and wrong answers obtained in KIDI in ascending order (for example G1E1 and G2E5, respectively).

\section{RESULTS AND DISCUSSION}

The data show that among the employees of the researched institution that were educators, 99\% were women, with ages between 21 and 56 years old, most (63\%) were parents and had finished high school $(51 \%)$. The others (49\%) were finishing or had finished graduation. It was also identified that about $70 \%$ had been working for more than 2 years in this kind of job.

The KIDI results will be presented considering the general analysis of the 75 questions that compose the instrument, as well as the discussion through the categories which guide it. Among the main results, it was verified that $66 \%$ of the educators answered correctly an average of 66 questions, 23\% answered 23 questions wrong, and $11 \%$ were in doubt in 11 questions. In general, the educators got more questions right than wrong, which allowed us to consider it a good performance in the knowledge test on child development. Nonetheless, it is noted that despite the good performance, more than $30 \%$ made mistakes or were in doubt concerning several questions that involved the investigated theme.

Another data that must be analyzed is the type of question the educators answered correctly, wrong, or were in doubt, according to the instruments' categories. The following table illustrates the mean percentage of right, wrong and uncertain answers for the 75 questions distributed among the four categories.

Table 1: Mean of right, wrong, and uncertain answers among educators regarding the KIDI's categories

$\begin{array}{lccc}\text { Categories } & \text { Right } & \text { Wrong } & \text { Uncertain } \\ \text { Care Practices } & 80 & 16 & 4 \\ \text { Health and Security } & 64 & 23 & 13 \\ \text { Norms and Acquisition } & 60 & 26 & 14 \\ \text { Dvelopmental Principles } & 68 & 22 & 10 \\ \text { General } & 66 & 23 & 11\end{array}$


In all four categories the educators obtained a percentage of right answers higher than $60 \%$. However, in the questions which compose the care practice category the educators answered correctly about $80 \%$ of the questions. On the other hand, norms and acquisition was the factor that had a lower mean percentage (60\%) when compared to the other three.

In a research developed by Silva et al. ${ }^{6}$ the questions in the health and safety category had the highest percentage of right answers, while the lowest score was of the 17 questions in the principles factor. Among the educators from the shelter it was observed a differentiated performance, as the 14 questions in the care practice category reached a higher percentage of right answers, on the other hand, the 32 questions regarding the norms and acquisition presented the lowest percentage. The care practices factor includes some aspects of the daily care experience with children, which primipara mothers, theoretically, don't have. The experience the caretakers accumulate in both conditions of professional and mother seem to provide relevant elements to explain such differences.

The greater percentage of right answers of the questions in this category among the professionals in the shelter institution may be due to the almost exclusive presence of women in this population. Literature data ${ }^{11}$ indicate that women have been busy with the physical care of children, be it as a mother, baby sitter, or teacher in basic education. Therefore, they gather experience at home as mother in addition to their professional area as educator. The care practice category gathers questions about the practical care that is culturally transmitted and that doesn't depend on technological or scientific advancements to be acquired. It also might represent a kind of knowledge usually acquired by educators for it requires the transmission of the gained experiences along the years working as caretakers of children, whether in the family or professional environment. However, for it to be easily transmitted it is noted that such knowledge tends to be seen as little complex and almost with no effect on the development.

Studies performed in collective care environments bring out the discussion on the educator's perception about the importance of its role as educator for the process of child development. Some studies ${ }^{11}$ point out the social depreciation of the educator's work in children sheltering institutions. Melchiori and Biasoli-Alves ${ }^{10}$ emphasized in researches with educators of day care centers about the people that have daily influence on the child's performance and temper, that the mothers' figure is considered the main source of influence, and the educators appear together with grandparents, parents, peers, and others. To Rogoff the performance of individuals dealing with children relates to the aspects that are part of the routine of the cultural community in which they are in and to habitual social practices. In this sense, it may be said that to understand different ways of taking care depends on personal, professional and cultural aspects.

The category norms and acquisition shows the lowest percentage of right answers and it involves the educator's knowledge about the most probable periods for the acquisition of motor, perceptual and cognitive skills, which are aspects that involve systematic advancements in the scientific and academic area. It was also noticed that, due to the population here studied the fact that the educators had finished high school or college didn't seem to assure them a formation based on contents about child development. Such factors may help explaining this lowest percentage of right answers. Therefore, for it might be a poorly disseminated knowledge in this population there is a difficulty in assimilating the advances science has demonstrated and that involve specific aspects of the development that are commonly investigated and propagated in the academic area, as for example, the findings in neuroscience.

With the data from the general performance of educators in the KIDI, it is necessary to present, then, such results connecting them to the characteristics of the socio-demographic profile of these professionals. Questions of this sort have been studied by authors that investigate child development and the hypothesis that certain characteristics are more important than others in the knowledge acquisition. Particularly, education has been known as a characteristic strongly related to the level of knowledge $4,5,6$.

For a more detailed analysis it was correlated the level of association between the score obtained in the KIDI and its subscales (categories) with variables as age, number of children, time of experience and education of educators. The values in Table 2 were determined by the non-parametric Spearman's Correlation Test ( $r$ ).

Table 2: Correlation between age, number of children, and time of service from educators and number of right answers in KIDI $(n=100)$

$\begin{array}{lcccc}\text { No of right answers } & \begin{array}{c}\text { Age } \\ \text { (years) }\end{array} & \begin{array}{c}\text { Number } \\ \text { of children }\end{array} & \begin{array}{c}\text { Service time } \\ \text { (months) }\end{array} & \text { Education } \\ \text { Care Practices } & 0.02 & -0.04 & 0.23 * & -0.08 \\ \text { Health and Security } & 0.15 & 0.19 & 0.06 & -0.12 \\ \text { Norms and Acquisition } & 0.01 & 0.21 * & 0.21 * & -0.05 \\ \text { Developmental Principles } & -0.12 & -0.01 & -0.01 & 0.09 \\ \text { General } & -0.03 & 0.15 & 0.19 & -0.05\end{array}$

* Spearman's Coefficient $(p<0.05)$ 
When analyzed the set of questions from KIDI it was noticed that the profile variables didn't exert significant influence for the level of knowledge on child development. However, when considering the categories one by one it was seen that there is an association of number of children and the scores in the norms and acquisition category $(r=0.21)$. It was also observed that the categories care practices and norms and acquisition are related to the time of experience ( $r=0.23$ and $r=0.21$, respectively).

In what concerns the age of the caretaker the results are in consonance with Ribas, Seidl de Moura and Bornstein ${ }^{5}$ who didn't find significance of the caretaker's age and the knowledge on child development in any category in KIDI.

About the education, it was not possible to presume it as a meaningful variable for the level of knowledge on child development. Such results are different than those found by Kobarg and Vieira ${ }^{4}$, and Silva et al. ${ }^{6}$ that identified the influence of education in the knowledge about child development. Therefore, it is possible to affirm that college education is not a relevant variable when it is discussed the knowledge on child development between the educators in a sheltering institution.

It is reassured, hence, how important it is to perform studies that investigate the knowledge professional caretakers have on child development, for there are many variables involved in this process and rare studies dedicated to this theme, specially involving educators from care institutions, such as shelters for children. With the aim of knowing peculiar characteristics of the subsystems that constitute the sheltering unit as a developmental niche $^{1,2}$ it is relevant to recognize the conceptions of development and care practices, and understanding them as inter-related subsystems that constitute it.

To what concerns the care practice subsystem, the data from this study are in reference to the time dedicated to activities performed by professions in play situations, which represents 36 hours of observation (from a total of 120 hours), besides the discussion on the care practice content. For a better presentation of the results the data will be shown according to the groups $\mathrm{G} 1$ and $\mathrm{G} 2$. G1 corresponded to the educators that had a higher percentage of right answers in the questions of the instruments and was composed of five educators. They answered correctly from 57 to 62 questions. The mean age of the educators from this group was 32 years, three of them completed high school and from the other two, one had finished college and the other hasn't. All of them had children and worked for more than 24 months in the institution. G2 was formed by the educators that had the highest percentage of wrong answers in the questions proposed by KIDI, answering from 23 to 27 questions wrong. Their mean age was 44 years, three of whom had finished college and two the high school. Concerning maternity three had children and more than 24 months experience in the institution.
It was identified that the educators in $\mathrm{G} 1$ dedicated 4 hours more in play activities when compared to the educators from $\mathrm{G} 2$. With this information in hand its made necessary to know how the educators from both groups developed in a specific manner their care practice in the observed situations as part of their routine in the institution.

Next some extracts of practices are presented focusing on the particularities found between both groups of educators in the attention given to the children. The extracts are grouped in bigger categories, adapted from Piccinini, Frizzo and Marin'.

The first category is in reference to the nature, function and rules of playing. The extracts are from educators from G1.

EPISOD 1: (...) C5 hits C6. G1E5 while puts on the sandals it says: "Hey C5!" and continues to put it on. C6 hits C5's head with the toy. G1E5 reaches out the hand in the toy direction and says: "Hey C6, it's not for you to hit with the toy on its head, it's to play with it" and continues to put it on. (...). (G1E5, D3).

EPISOD 2: G1E4 walks through the shed and goes to hammock in which C52 is swinging C51 and says: "hey, slowly, it's for everybody". Goes to the next hammock in which C49 swings C53 and says: "slowly, it's too high" (...) G1E4 looks at C53 who is in the hammock and says: "Hey C53, what did I tell you?" (...) It looks again to C53 and says: "Hey C53, less, less." The boy swings the hammock very high, distant from the floor. (G1E4, D7).

This category here discussed can also be found among the educators from G2, according to the next extracts.

EPISODE 3: G2E9 looks at C53, goes to its direction and says: "Come on, give me" and reaches out the hand. C53 says: "No, go there". (...) G2E9 says: "Come on kid, before we jump we'll lose the will" and smiles. It says: "Come on, turn it, turn it now. Leave C44, leave because now it's me, now!" and it skips the rope. C53 chants the regional rhyme: "the man knocked on my door and I opened" (...). C53 starts to skip and the rope hits its leg. G2E9 says: "Get out", she hoots C53: "Boooo!! (...) (G2 E9, D7)

EPISODE 4. (...) C12 and C13 are jumping on some beds. It keeps looking at the girls that are playing and says: "Hey girl (C13), don't push her (C12), don't push her". C13 gets a toy from the floor and threatens to throw at C12. G2E7 says: "Hey, hey, hey C13". $\mathrm{C} 12$ runs to the observer and $\mathrm{C} 13$ goes after her. G2E7 says: "C13!". C12 hits C13 and the girl cries. G2E7 looks and says: "come here 
C12, sit here". C12 goes in the educator's direction. (...) (G2E7, D4).

A striking difference between the participants' practices in the described extracts involves the orientation based on explanations. Among the educators from $\mathrm{G} 1$ the orientations to the children were usually followed by the questioning of the reasons, for explaining the reason why it could not do this or that, and also emphasized the reason not to do something they would like. It was observed that the rules involved in playing were more clearly expressed by the educators from $\mathrm{G} 1$.

Martins and Szymanski ${ }^{14}$ indicate that actions directed to explicit examples tend to have satisfactory effect when the topic is rule following and assimilation by the children about what can or cannot be done. These authors emphasizes yet that the more structured and organized the environment with norms, ruled and objects involved the more is the possibility for the child to learn living experiences provided by the playing, besides promoting in a satisfactory way the learning and the education involved in the activity.

One aspect that calls our attention between the educators from $\mathrm{G} 1$ is to introduce elements that are part of the local culture in the plays as it is seen in Episode 2 in which the child plays swinging in a hammock brought for the institution by the educator. This practice can be considered very relevant when it is investigated the role of the culture in the care practice development ${ }^{1,7,8}$. In a way the adoption of practices of such nature recuperate regional cultural habits, as well as the experiences lived in the coexistence with the parents and other relatives, which can provide an environmental setting with clear characteristics of a family.

Another characteristic emphasized in play situations involves the stimulation, encouragement and challenge about splitting and sharing the toys and plays. The next extracts illustrate the occurrences of practices in G1.

EPISODE 5: (...) C25 gives something to the educator that smells it and says: "you don't even have a toy pan to make food, let me get one" and walks around the house and gets two boxes that seem like two stools. G1E2 says: Where is the pan? Where is the pan?". Put the Box on the sidewalk in front of the house and asks: "Is it the stove?". C28 says: "I want to sit, aunt". G1E2 says: "No, it's not to sit on, it's the stove to make food". Holds C28 by the arm and says: "Go there, it's not C28's chair, it's the stove". (...) G1E2 gets another toy and says: "Look here, another pan. Do you know what a pan is? Do you? Do you know what a pan is? Hun? Do you know what a pan is? (...) G1E2, D5)

EPISODE 6: (...) it keeps walking and says to C14: "Come on, I don't want to know about a fight for the broom, each one is going to sweep a little, when finished lends it to the peer. I don't want cry or fight. If you fight I'll get the broom and no one plays". (...) Goes to the front of the house, take something from the floor and says looking at C12: "Then you lend it to your friend, okay C12". (..) G1E3 opens the doors and says: "Already? Now it's my turn, its C15's turn, come on". (...) (G1E3, D4).

Among the educators from G2 it may also be found practices of this sort, as demonstrated by the next extracts.

EPISODE 7: (...) all the children come close to the bed on which the educator is sit. G2E6 pulls C40 and says: "Come here my daughter, tell a story" and the girl starts to tell "once upon a time...". The other children come close shouting and G2E6 says: "Hey, excuse me, I'm listening to a story here". G2E6 shows attention to the story that C40 tells, motivating it. G2E6 says: "hey $\mathrm{C} 41$ " and the boy sits close, and says again: "Hey C42", and the boy goes to the educator. She says: "Sit there". It keeps saying: "C40 is going to tell us a story. Every night I tell, today its gonna be her". (...) G2E6 crouches and says to C42: "C42 pay attention". It calls another child that was far away playing: "Hey C43, hey $\mathrm{C} 45$ come here that $\mathrm{C} 40$ is going to tell a story, you cannot be talking". (...) (G2E6, D6). EPISODE 8: (...) C25 chants a regional nursery rhyme. G2E9 chants it too. Looks at C31, touches its head and says: "you better defend yourself! Because from now on...". G2E9 turns around and do something on the shelf. C27 hits C31, C31 hits him back. G3E9 stops the fight and says: "Hey, hey, hey". C24 leaves the dormitory. (...) (G2E9, D5).

As it seems, the educators from $\mathrm{G} 2$ rarely make use of strategies to motivate the participation of children in play activities. In this regard, such posture was more frequently found in G1. Episode 8 shows how much the educator was aligned to the behavior of one particular child, especially when it completes the song the girl was singing.

It was also observed that from the themes involved in the plays it is common to play "house" among the educators from G1. It's a make believe play that redeem the family life and keeps alive in the children's memory the experiences of living with the parents, siblings, and other relatives, as for example the moment for preparing the meal and cleaning the house, which were identified in episodes 5 and 6 , respectively. It is understood that this kind of play enables the child to socialize its family experiences and relate them to the experiences in the shelter institution. Still on the subject, Martins e Szysmanski ${ }^{14}$ emphasize that such 
activities highlight aspects related to the daily living, involving actions brought from the family routine, especially the ones that involve the mother figure. In this sense, the data from the play routine in the sheltering institution show that the educator from G1 stimulated and incorporated activities in which the child may have had as part of its family living. It is understood that, in these circumstances, to keep the experience of a domestic life alive in the child's memory may be important for those that are in sheltering situation, especially for a long time in this environment. The same way, it also enables to demonstrate to those children that didn't have any or few experience with the family the activities of the daily life.

The involvement of the educator in the child's make believe world and other ways of play expression suggest a discussion about their involvement in these moments. Comparatively, it was observed a striking characteristic that commonly involves playing together and supervising the play. Among the educators from $\mathrm{G} 1$ it was identified that they interact in a very marked way with the children, showing the functions and forms of playing. It seems that this group valued the participation of the educator's figure in these situations. Literature ${ }^{1,2,3,14}$ data emphasize the importance of a more experienced figure in the relation with the child through its development. The play tends to be a privileged moment of social interaction for both dyads child-child and child-adult. It is understood that the presence of an experienced adult enables the learning of how to play and behave in group, with specification of rules and aspects of the daily basis.

However, it was also verified that professionals from G1 played more frequently with the children, fully participated of the play moments and were active members in the play. In this sense, they played the role of who orients, commands, and manages the interactions and who was an equal participant that is commanded by the child's instructions and suggestions. Among the educators from $\mathrm{G} 2$ it was seen that the play moment tend to be marked by supervision of the play, and the orientation is given by someone apart from the activity. Martins e Szymanski ${ }^{14}$ remind us that the educator's presence helps systemizing the rules and behaviors and in managing conflicts, however, when the adult places itself as a character along with the child in the activity such teachings may be more effective.

On the other hand, the presented extracts from G2's educators clearly demonstrate the little participation in the play by the educator. In a research performed by Cordazzo and Vieira ${ }^{13}$ it is possible to see that some studies about the playing emphasize the importance of allowing the child to play free, to innovate and give a new meaning to the moment. They highlighted that, in their opinion, the adults' interventions must accentuate the child's creative imagination, focusing on developing skills.
However, in this study, on Episode 7, it was noticed that the educator's intervention had little effect when dealing with the moment in which a child was telling a story. In this specific case there were two groups of children that were performing different activities. The educator's intervention was based on the aim of giving emphasis to one of the plays. For that it disrupted the initiative of one of the groups, possibly explaining the lack of interest of some of them for the activity proposed by the educator.

The third category involves teaching of concepts and the right pronunciation. The next extracts show this category among educators from $\mathrm{G} 1$.

EPISODE 9: (...) C44 says: "Aunt, I want to ope (open), aunt I want to ope your tabinet (cabinet)". G1E3 says: "Cabinet". C44 "I want to ope aunt" G1E3 says: "Cabinet, what is the name? Say cabinet". C44 says: "Tabinet". G1 E3 says: "Cabinet. Say Ca". C44 says: "Ta". G1E3 says: "Ca". C44 says: "Ta". G1E3 says: "Ca. Say it". C44 says: "Tabinet, let me ope aunt, I want to ope it" (...) (G1E3, D4)

EPISODE 10: (...) C56 says: "I'm only going to cut women with clothes" G1E4 asks: "Only women with clothes, why?". C56 while turning the pages says: "Because we can't cut women without clothes", G1E4 says: "we can't? Why?" C56 says: Because God doesn't let us". G1E4 asks: "God doesn't let us?". The educator turns to the girl pointing to the picture and says: "Look, she is with a bikini, there's no problem. When we go to a swimming pool don't we wear a bikini?". C56 nods positively. G1E4 says: "So, so there's no problem". (...) C56 while cutting the magazine says: "Naked is not allowed, right aunt?" G1E4 says: "right, naked is not allowed". C56 says: "If we cut then God is going to ground us". G1E4 says: "It's going to ground us?" while caressing the girls' hair, it says: "But God doesn't ground us". C49 says: "Only punishes, right aunt?" G1E4 says: "No, God doesn't punish. He doesn't like, but he doesn't punish". (...) (G1E4, D7).

Such aspects were also found in the educators from G2, as presented in the next extracts.

EPISODE 11: (...) G2E9 rights again in the occurrence. C53 says to C52: "I gived to him (C51) what C28 gived me", G2E9 looks and says: "It's not I gived, it's I gave". (...) (G2E9, D7)

EPISODE 12: (...) G2E9 looks around. A thunder is heard. C34 approaches and says: "See, it's the Father". (...) G2E9 says: "See, the Father is fighting". (...) (G2E9, D5)

Teaching the right pronunciation, sharing religious values, stopping aggressive behaviors and 
stimulating the pro-social behavior are aspects found in the practices extracts. It was seen that the educator intervenes with the child when notices it speaking incorrectly. On the other hand, when this practice is compared between the groups it is observed that educators from G1 more frequently point out the mistake, correct it and stimulate the child to speak correctly, an aspect little found between the educators from G2. For example, the notion of God is explicitly presented by the educator from $\mathrm{G} 2$ in the Episode 18, as a person that fights and punishes the children, differently from the notion presented by the educator from $\mathrm{G} 1$, in episode 10, previously described.

In a general way, the educators from G2 assumed a more directive posture, without further explanations and justifications on why they should or not behave in certain ways in that moment. Among the educators from $\mathrm{G} 1$ such behaviors are valued through the signalization of what is considered wrong and the stimulation of what is considered right. In this last one it was observed that he educator identifies the importance of such conduct and the reasons for the child to behave that way. From what is reported, Rogoff emphasizes that the strategies are guided by the educator's conception of morality of what is adequate and inadequate in the community they are part. Which brings back to the perspective of developmental niche when highlighting that the care practices reflect some aspects of the caretakers' psychology and the environment in which they occur ${ }^{1,3}$.

\section{FINAL CONSIDERATIONS}

This study aimed at identifying and analyzing the descriptors of existing relation between what is thought and done by two groups of child caretakers (G1 and G2), in a given institutional environment. The data show that some characteristics of educators from G1 as being mothers, young, with longer professional experience in taking care of children, and a high knowledge on child development are relevant for the quality of the observed practices. It may be said that the considerably high level of knowledge on child development and the recognition of quality care practices in this group seemed to be strongly associated to the practical experience as mothers and educators.

\section{REFERENCES}

1 Harkness S., Super CM. Parental ethnoteories in action. In: Sigel IE, McGillicuddy-DeLisi AV, Goodnow, J] (Orgs.), Parental belief systems: The psychological consequences for children. Hillsdale: Lawrence Erlbaum, 1992. p. 373-391.

2 Harkness S., Super CM. The developmental niche: a theoretical framework for analyzing
The data show evidences of how the educator seeks to provide conditions for the care quality to be assured, having, therefore, an active role. In this sense, the results point that the educator is influenced by the physical and social environment, as well as provide changes and alterations in its structure. Similarly, it was seen that such professional gathers knowledge from different components of its life for performing its tasks as an educator that deals with children in a shelter environment. Therefore, it is concluded that regarding the child, the educator is part of the developmental niche, assimilating characteristics of this ecological context and incorporate them into its practices, but also produces it and transforms it in the sense of accommodating its individual actions and behaviors, brought from their personal and family experiences to the care routine.

As a result, the adult, along with the child, play an active role on the construction, modification and maintenance of the niche. The adult interacts with the environment through its cultural baggage and changes it according to its needs and also the child's needs. In a certain way, the environment modification may occur to favor itself and its work, as well as to provide the child's well being. In fact, this study points out that the educator relate to the children and make use of certain care practices, depending on the physical and social environment, bringing them close to their own needs and the children needs.

With this article it as intended to contribute to the understanding of the shelter environment as part of the child's developmental niche. In addition, this study aimed at bringing out the discussion on the quality of the environments and the care practices that are being offered to the children that have fragile family bonds. Therefore, investment and changes must be done to provide, as possible, healthy life quality for these children that frequently come to care institutions. It's is also important to highlight the need for investments in capacitating the educators focusing on the care routine and practices adopted, especially in common daily lives situation. Lastly, as it was also tried to show, the educator must be thought as an active subject interacting with the developmental niche, which carries with it an infinity of elements that need and must be considered when collective care environments are studied in this theoretical perspective.

the household production of health. Soc Sci Med. 1994, 38 (2): 217-26.

3 Harkness S., Super CM. Parents' cultural belief systems: their origins, expressions and consequences: Introduction. New York, US: The Gilford Press, 1996. p. 1-23.

4 Kobarg APR, Vieira ML. Crenças e Práticas de Mães sobre o Desenvolvimento Infantil nos Con- 
textos Rural e Urbano. Psicologia: Reflexão e Crítica. 2008, 21(3): 401-408.

5 Ribas RCJr., Seidl de Moura ML, Bornstein MH. Cognições maternas acerca da maternidade e do desenvolvimento humano: uma contribuição ao estudo da psicologia parental. Rev. Bras. Crescimento Desenvolv. Humano. 2007, 17 (1), 104-113.

6 Silva AK, Vieira ML, Seidl de Moura ML, Ribas RCJr. Conhecimento de mães primíparas sobre desenvolvimento infantil: um estudo em Itajaí, SC. Rev. Bras. Cresc. Desenv. Hum. 2005, 15 (3), 01-10.

7 Rogoff B. A natureza cultural do desenvolvimento humano. Porto Alegre: Artmed, 2005. p. 15-60.

8 Super CM. Environmental effects on motor development: The case of 'African infant precocity'. Develop. Med. Child Neurol. 1976, 18, $561-567$.

9 Piccinini CA, Frizzo GB, Marin AH. Interações diádicas e triádicas em famíllias com crianças de um ano de idade. In: Piccinni CA, Seidl de Moura ML (Org.). Observando a interação pais - bebê - criança. São Paulo: Casa do Psicólogo, 2007. p. 176-211.

10 Melchiori LE, Biasoli-Alves ZMM. Crenças de educadoras de creche sobre temperamento e desenvolvimento de bebês. Psicologia: Teoria e Pesquisa. 2001, 17 (3), 285-292.

11 Magalhães CMC, Costa LN, Cavalcante LIC. Percepção de educadores de abrigo: o seu trabalho e a criança institucionalizada. Rev. Bras. de Cresc. e Desenv. Hum. 2011, 21 21(3): 818-831.

12 Moré CLOO, Sperancetta A. Práticas de pais sociais em instituições de acolhimento de crianças e adolescentes. Psicologia \& Sociedade. 2010, 22 (3): 519-528.

13 Cordazzo STD, Vieira ML. A brincadeira e suas implicações nos processos de aprendizagem e de desenvolvimento. Estudos e pesquisa em Psicologia. 2007, 7(1): 89-101.

14 Martins E, Szymansky H. Brincando de casinha: significado para crianças institucionalizadas. Estudos de Psicologia. 2004, 9 (1): 177-187.

15 MacPhee D. Manual for the Knowledge of Infant Development Inventory. Manuscrito não-publicado, University of North Carolina, 1981. p. 1-8.

16 Seidl de Moura ML, Ribas RCJr, Piccinini CA., et al. Conhecimento sobre desenvolvimento infantil em mães primíparas de diferentes centros urbanos do Brasil. Estudos de Psicologia. 2004, 9 (3): 421-429. 